\title{
Evaluating the variability of the modulus of elasticity of concrete through the use of different types and batches of aggregate
}

\author{
Alex Taira de Vasconcellos ${ }^{1}$, Paulo Ricardo de Matos ${ }^{1,2}$, Cézar Augusto Casagrande ${ }^{3}$, \\ André Valmir Saugo Ribeiro ${ }^{1}$, Luiz Roberto Prudêncio $\mathrm{Jr}^{1}$.
}

\author{
${ }^{1}$ Universidade Federal de Santa Catarina (UFSC), Departamento de Engenharia Civil, Rua João Pio Duarte Silva, 205, \\ 88037-000, SC, Florianópolis, Brasil. \\ ${ }^{2}$ Universidade Federal de Santa Maria (UFSM), Coordenadoria Acadêmica, Rodovia Taufik Germano, 3013, 96503-205, \\ RS, Cachoeira do Sul, Brasil. \\ ${ }^{3}$ Universidade Federal de Pernambuco (UFPE), Núcleo de Tecnologia do Campus do Agreste, Av. Marielle Franco, s/n - \\ Km 59, Nova Caruaru, 55014-900, PE, Caruaru, Brazil. \\ E-mail: alex.taira@hotmail.com, paulorm.matos@gmail.com, cezar.acasa@gmail.com, \\ andrecivilutfpr@gmail.com, prudenciouk@hotmail.com
}

\begin{abstract}
The modulus of elasticity of concrete is often calculated as a function of the compressive strength, and as a deterministic value. However, variations in the aggregates properties may result in module values different than those estimated, which may lead to excessive deformation and eventual instability of the structure. In this work, the influence of the coarse aggregate batch variation on the variability of the modulus of elasticity of the concrete was investigated. Three different aggregate sources (one of granite origin and two of gneiss origin), three water/cement ratios (w/c) and five different batches of each aggregate were investigated. The compressive strength and static modulus of elasticity of the concretes were determined at 28 days. The analysis of variance (ANOVA) showed that the variable "batch" had a significant influence on the modulus of elasticity of the concrete, indicating that this property is a probabilistic variable indeed. The normality of the distribution of its values was attested, and values of characteristic modulus of elasticity were proposed, which were from 6 to $10 \%$ lower than the mean values. In addition, the use of gneissic aggregates led to modulus of elasticity values $30 \%$ higher than those of the concretes with granitic aggregates and equivalent compressive strengths, while the reduction of the w/c ratio from 0.71 to 0.46 increased the modulus of elasticity in about $5 \%$.
\end{abstract}

Keywords: Aggregate; Concrete; Modulus of elasticity; Variability.

\section{INTRODUCTION}

The construction of tall buildings in reinforced concrete has become a common practice in South America, eventually exceeding 250 meters in height [1]. In addition to the obstacles encountered in the execution of these buildings, a challenge for structural projects is the rigidity required by these structures, since they are often slender buildings. This demand leads to the need for concretes with high elasticity modules.

The importance of such a property is demonstrated by the existence of numerous researches related to the theme. PARRA et al. [2] evaluated the difference in the elasticity module of conventional and selfcompacting concretes, with the same compressive strengths. The authors found that the modulus of elasticity of the pastes that make up the self-compacting concretes tends to be higher, due to the presence of mineral additions which promote greater compactness of the cementitious matrix. However, the presence of higher volumes of paste in this type of concrete led to slightly lower modulus of elasticity. ABED et al. [3] investigated the residual mechanical properties of self-compacting concrete incorporated with unprocessed waste fly ash after expose to the elevated temperature. The authors found that the modulus of elasticity is more sensitive to high temperature exposure than other mechanical strength (e.g. compressive and flexural strength), and replacing cement with up to $15 \%$ waste fly ash improved the residual modulus of elasticity of concrete. ALSAMAN et al. [4] evaluated the elasticity modulus of ultra-high performance concrete, made 
with a w/c ratio equal to 0.20 and only natural small aggregates, with a maximum diameter of $1.0 \mathrm{~mm}$. For strengths of 130 to $160 \mathrm{MPa}$, elastic modules of 38 to $46 \mathrm{GPa}$ were obtained. SILVA et al. [5] evaluated the modulus of elasticity of concretes containing recycled aggregates, observing values lower than those obtained for concretes with conventional aggregates. According to the authors, this occurred due to the lower modulus of elasticity of the recycled aggregates and the characteristics of the paste / aggregate transition zone. Piesta et al. evaluated the correlation between the modulus of elasticity of conventional and high-performance concretes, and of the rocks that originated the aggregates (basalt, granite, dolomite and quartz). The modulus of elasticity of basaltic rock was $100.8 \mathrm{GPa}$, while of granite it was $28.0 \mathrm{GPa}$. This resulted in modules of elasticity 25 to $45 \%$ higher for concretes containing aggregates of basalt compared to those containing granite, for same w/c ratios. The same behavior was observed by JUROWSKI and GRZESZCZYK [6], who investigated the elasticity module of self-compacting and high-performance concretes produced with natural and basalt aggregates. SCHANKOSKI et al. [7] found that the mineral origin of the filler used in selfcompacting concrete significantly affects the modulus of elasticity of the composite, observing values up to $16 \%$ higher for concretes produced with granite and diabase fillers, compared to those produced with fillers. limestone. In addition to the various correlations proposed in the literature, models for predicting codes and standards are available, such as Model Code [8], ACI 318 [9], and Brazilian [10], British [11], Spanish [12], New Zealand [13], and Canadian [14] standards.

A fact neglected both by the models and correlations presented in the literature and in structural projects is the possible variability in the value of the concrete's modulus of elasticity. In contrast to the compressive strength, for which a characteristic value is adopted due to the dispersion of its values, the modulus of elasticity is approached as a deterministic variable. Thus, the occurrence of values lower than the one adopted may result in calculation errors and lead to excessive deformations, or even to instability of the structure. In this context, to the authors' best knowledge, reports of the variability of the modulus of elasticity of concretes produced with aggregate from the same source over time are non-existent.

Therefore, this work evaluated the influence of the variation of the batch of the coarse aggregate in the variability of the elasticity module of the concrete. For this, concretes were made with coarse aggregates from three different sources, three different water/cement ratios, and five different batches from each source of aggregate. The compressive strength and static elastic modulus of the concretes were determined at 28 days. Based on the results obtained, a probabilistic approach is proposed for the modulus of elasticity, determining a characteristic value for this property.

\section{MATERIALS AND METHODS}

\subsection{Materials}

Portland cement available in Brazil as CP IV-32 [15] was used, equivalent to CEM II/A-V [16]. The chemical and physical characteristics of the cement are presented in Table 1. As fine aggregate, a combination of two sands was used: quarzitic natural sand with fineness modulus of 1.04 and density of 2.65 $\mathrm{g} / \mathrm{cm}^{3}$, and limestone manufactured sand with fineness modulus of 3.03 and density of $2.80 \mathrm{~g} / \mathrm{cm}^{3}$. The combination of $60 \%$ natural sand $+40 \%$ manufactures sand was used since it was previously defined as the optimum proportion [17], resulting in a composition with fineness modulus of 1.84 and density of $2.71 \mathrm{~g} / \mathrm{cm}^{3}$. The particle size distribution of the fine aggregate used is presented in Figure 1.

Table 1: Chemical and physical characteristics of the Portland cement used.

\begin{tabular}{|c|c|c|c|c|c|c|c|c|c|c|}
\hline \multicolumn{11}{|c|}{ Chemical composition } \\
\hline $\mathrm{SiO}_{2}$ & $\mathrm{Al}_{2} \mathrm{O}_{3}$ & $\mathrm{Fe}_{2} \mathrm{O}_{3}$ & $\mathrm{CaO}$ & $\mathrm{K}_{2} \mathrm{O}$ & $\mathrm{Na}_{2} \mathrm{O}$ & $\mathrm{MgO}$ & $\mathrm{SO}_{3}$ & LOI & IR & Free $\mathrm{CaO}$ \\
\hline 28.99 & 9.79 & 4.07 & 45.45 & \multicolumn{2}{|l|}{$* 1.18$} & 2.41 & 2.59 & 3.24 & 26.10 & 0.67 \\
\hline \multicolumn{11}{|c|}{ Physical properties } \\
\hline \multicolumn{4}{|c|}{ Density $\left(\mathrm{g} / \mathrm{cm}^{3}\right)$} & \multicolumn{3}{|c|}{ Blaine fineness $\left(\mathrm{cm}^{2} / \mathrm{g}\right)$} & \multicolumn{4}{|c|}{ 28-day nominal strength (MPa) } \\
\hline \multicolumn{4}{|l|}{2.86} & \multicolumn{3}{|l|}{4380} & \multicolumn{4}{|l|}{43.3} \\
\hline
\end{tabular}

* $\mathrm{Na}_{2} \mathrm{O}$ equivalent; $\mathrm{LOI}=$ loss on ignition; $\mathrm{IR}=$ insoluble residue. 


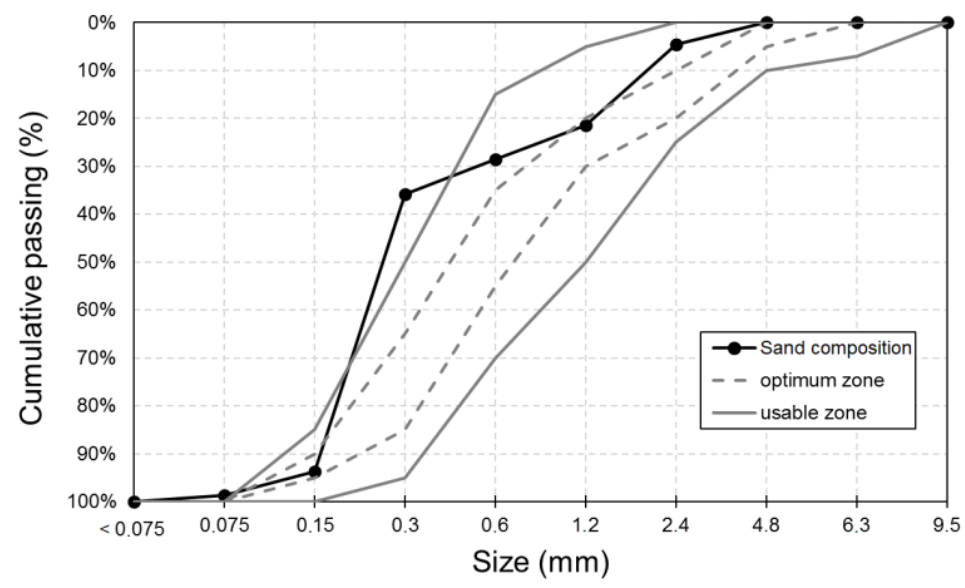

Figure 1: Particle size distribution of the fine aggregate used.

Three gravels were used as coarse aggregate: one granitic, produced in Tijucas, SC, Brazil (referred to as "Granite"), and two gneissic, one of which was produced in Blumenau, SC, Brazil (referred to as "Gneiss 1") and the other in Gaspar, SC, Brazil (referred to as "Gneiss 2"). For each gravel, 5 samples were collected on different dates, collected in two size fractions: $4.75-12.5 \mathrm{~mm}$ and 9.5-25.0. For concrete production, the two size fractions were used in equal proportions. The particle size distribution of the coarse aggregates of different types and batches are shown in Figure 2, their physical characteristics are presented in Table 2.

Table 2: Physical characteristics of the coarse aggregates from different types and batches.

\begin{tabular}{|c|c|c|c|c|c|c|c|c|}
\hline Material & / size fraction & Property & Batch 1 & Batch 2 & Batch 3 & Batch 4 & Batch 5 & Average \\
\hline \multirow{4}{*}{ Granite } & \multirow{2}{*}{$4.75-12.5 \mathrm{~mm}$} & Density $\left(\mathrm{g} / \mathrm{cm}^{3}\right)$ & 2.60 & 2.60 & 2.62 & 2.62 & 2.62 & 2.61 \\
\hline & & Fineness modulus & 6.42 & 6.44 & 6.46 & 6.45 & 6.42 & 6.44 \\
\hline & \multirow{2}{*}{$9.5-25.0 \mathrm{~mm}$} & Density $\left(\mathrm{g} / \mathrm{cm}^{3}\right)$ & 2.61 & 2.60 & 2.63 & 2.62 & 2.62 & 2.62 \\
\hline & & Fineness modulus & 6.98 & 7.09 & 7.10 & 7.06 & 7.03 & 7.05 \\
\hline \multirow{4}{*}{ Gneiss 1} & \multirow{2}{*}{$4.75-12.5 \mathrm{~mm}$} & Density $\left(\mathrm{g} / \mathrm{cm}^{3}\right)$ & 2.75 & 2.78 & 2.76 & 2.78 & 2.80 & 2.77 \\
\hline & & Fineness modulus & 6.35 & 6.24 & 6.21 & 5.89 & 6.02 & 6.14 \\
\hline & \multirow{2}{*}{$9.5-25.0 \mathrm{~mm}$} & Density $\left(\mathrm{g} / \mathrm{cm}^{3}\right)$ & 2.78 & 2.78 & 2.76 & 2.77 & 2.80 & 2.78 \\
\hline & & Fineness modulus & 6.97 & 6.94 & 6.92 & 7.02 & 7.03 & 6.98 \\
\hline \multirow{4}{*}{ Gneiss 2} & \multirow{2}{*}{$4.75-12.5 \mathrm{~mm}$} & Density $\left(\mathrm{g} / \mathrm{cm}^{3}\right)$ & 2.85 & 2.85 & 2.81 & 2.84 & 2.80 & 2.83 \\
\hline & & Fineness modulus & 6.02 & 6.09 & 4.98 & 6.12 & 5.68 & 5.78 \\
\hline & \multirow{2}{*}{$9.5-25.0 \mathrm{~mm}$} & Density $\left(\mathrm{g} / \mathrm{cm}^{3}\right)$ & 2.85 & 2.85 & 2.81 & 2.84 & 2.78 & 2.83 \\
\hline & & Fineness modulus & 6.98 & 6.94 & 6.97 & 2.05 & 7.01 & 5.99 \\
\hline
\end{tabular}



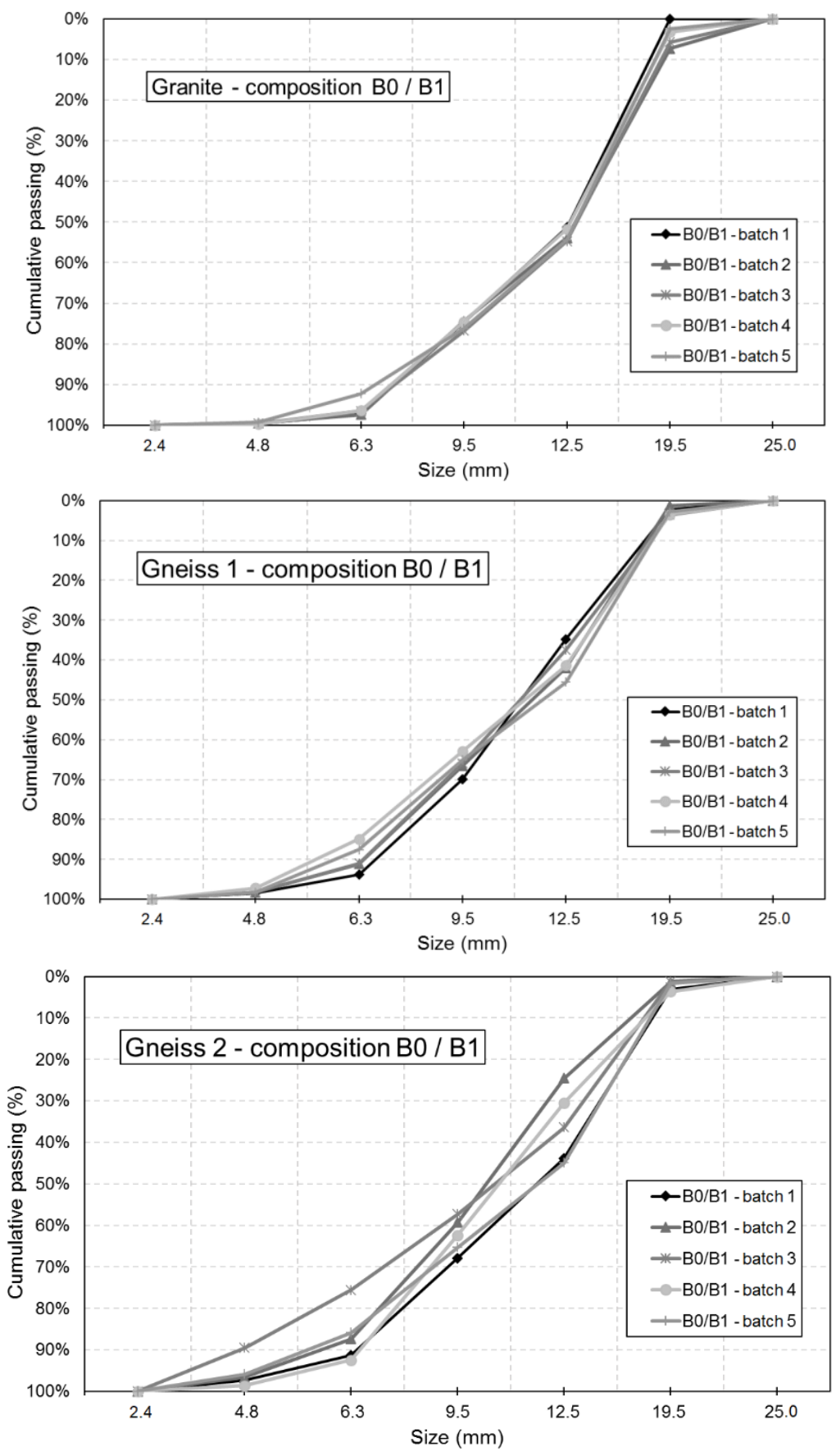

Figure 2 Particle size distribution of the different types and batches of coarse aggregate.

\subsection{Mix proportioning}

Firstly, a water content of 174 liters $/ \mathrm{m}^{3}$ and a volumetric mortar content of 59\% were fixed for all the mixes, which were previously verified as adequate for producing concretes with the materials commercially available in the region [18]. Then, the cement content was varied to reach compressive strengths compatible with those used in practice (i.e. from 25 to $40 \mathrm{MPa}$ ), therefore establishing three water/cement (w/c) ratios by mass: $0.46,0.57$ and 0.71 . The volumetric content of coarse aggregate was fixed (in about $41 \%$ ) in order to verify only the effects of the aggregate type and batch - and not of its content - on the mechanical properties of concrete. Finally, the fine aggregate content was defined as the volume necessary to complete $1 \mathrm{~m}^{3}$ of concrete. Figure 3 illustrates the detailed composition of the concretes investigated, in volumetric basis. Considering three types of coarse aggregate, five batches of each aggregate, and three w/c ratios, a total of 45 concretes were produced. 


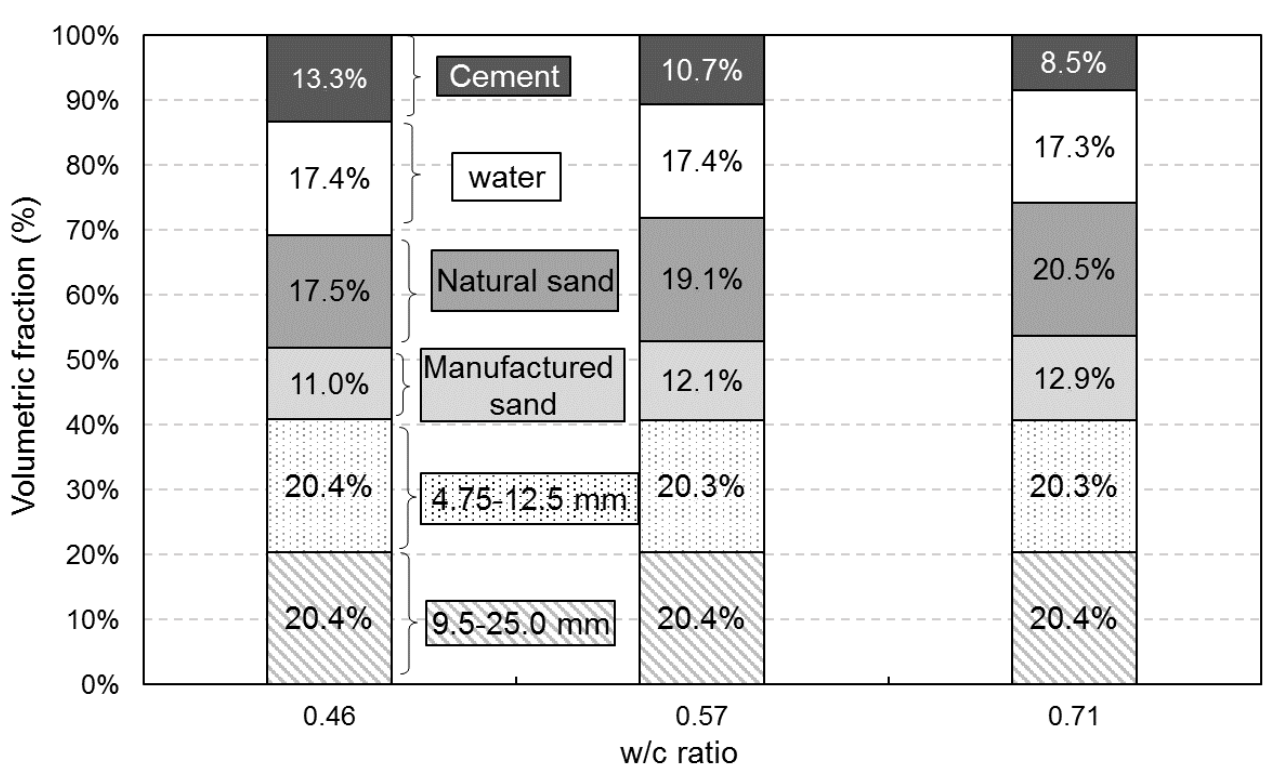

Figure 3: Volumetric proportioning of the concrete mixes investigated.

\subsection{Sample preparation}

Concretes were prepared in a vertical axis mixer with capacity of 35 liters and $60 \mathrm{rpm}$. For each composition, batches of 15 liters were prepared, mixed according to the following steps: (i) addition of cement and sand to the mixer container and homogenizing for $1 \mathrm{~min}$; (ii) addition of water gradually over $1 \mathrm{~min}$; (iii) after a total of 4 min mixing, adding the gravel; (iv) after a total of 5 min mixing, gradually adding the plasticizer until reaching the desired consistency; (v) mix up to a total of $10 \mathrm{~min}$. The aggregates were previously dried, and the materials were stored in the laboratory for 24 hours before using for temperature stabilization.

Immediately after the concrete preparation, the slump test was conducted according to ASTM C143 [19] to check if the workability reached the desired target of $150 \pm 30 \mathrm{~mm}$, in addition to determining the entrained air content by the gravimetric method according to ASTM C185 [20]. Then, six cylindrical specimens of 100 in diameter and $200 \mathrm{~mm}$ in height were cast according to ASTM C39 [21]. Immediately after casting, the specimens were placed in room wt $23.0 \pm 2.0^{\circ} \mathrm{C}$ for $24 \mathrm{~h}$. Then, they were demolded and immersed in a water tank saturated with lime, where they were kept until 28 days.

\subsection{Testing methods}

The compressive strength tests were conducted according to ASTM C39 [21], and the modulus of elasticity of concrete was determined according to ASTM C469 [22]. Both tests were performed at 28 days using a UH-2000 (Shimadzu) hydraulic press, with constant loading rate of $0.45 \pm 0.10 \mathrm{MPa} / \mathrm{s}$.

\subsection{Statistical analysis}

Analysis of variance (ANOVA) was used to verify the influence of the parameters "w/c ratio", "type of aggregate", "batch of aggregate", and the combination between them in the compressive strength values and modulus of elasticity of concrete. The analysis was performed using the software Statistica (version 13.2), for 95\% reliability.

The normality of the results was verified by the Kolmogorov-Smirnov Normality Test. This method consists of comparing the cumulative frequencies of the values obtained experimentally with those of the theoretical normal distribution. To accept the normality of the data, the maximum absolute difference between the observed and theoretical distributions must be less than a critical value, which depends on the significance and size of the sample [23]. This comparison is conducted using Equation 1, where Dn is the observed difference, $F(x)$ is the assumed cumulative distribution function (in this case, the normal function), and $F n(x)$ is the cumulative distribution obtained experimentally (i.e. empirical distribution).

$$
D n=\sup _{x}\left|F(x)-F_{n}(x)\right|
$$

The empirical distribution function $F n(x)$ is defined by Equation 2, for $n$ independent $X i$ observations, 
where $I_{[-\infty, x]}\left(X_{i}\right)$ is the indicator function (equal to 1 if $X i \leq x$, and equal to 0 if $X i>x$ ).

$$
F_{n}(x)=\frac{1}{n} \sum_{i=1}^{n} I_{[-\infty, x]}\left(X_{i}\right)
$$

The observed difference $(D n)$ is then compared with the critical value $D(\alpha, n)$, which depends on the level of probability $(\alpha)$ and the sample size $(n)$. If $D n$ is lower or equal to $\mathrm{D}(\alpha, n)$, the hypothesis of normality is accepted.

If the normality of the values is confirmed, a characteristic value can be determined from the t-student distribution given by Equation 3, where $\bar{x}$ is the sample mean, $\mu$ is the population mean, $\mathrm{s}$ is the sample standard deviation and $n$ is the number of values. The characteristic value corresponds to the value that, for the adopted reliability, values below it will not be achieved.

$$
t=\frac{\bar{x}-\mu}{s / \sqrt{n}}
$$

\section{RESULTS AND DISCUSSION}

The characterization of concrete in the fresh state was limited to determining its slump as an accepctance criterion. All the mixes reached the initially established range of $150 \pm 30 \mathrm{~mm}$. In addition, the air content of the concretes varied from 1.2 to $3.1 \%$, therefore not significantly affecting its mechianical properties.

\subsection{Compressive strength of concrete}

Although the major goal of this work is to check the variability of the module of elasticity of concrete with different batches of aggregate, it is convenient to verify if the compressive strength of the concrete was affected. The compressive strength results at 28 days are shown in Figure 4. The mean strengths were 40.0, 31.1 and $22.2 \mathrm{MPa}$, respectively for the w/c ratios of $0.46,0.57$ and 0.71 . It can be notet that the type of aggregate did not have significant influence on the compressive strength of concrete, and this trend was confirmed by ANOVA presented in Table 3, in line with that reported by [24]. For conventional strength concrete (i.e. with compressive strenght up to $60 \mathrm{MPa}$ ), the aggregate usually presents strength greater than the cementitious matrix. Thus, the failure of the composite tends to occur in the matrix, while the type of aggregate generally does not significantly influence the strength of concrete as long as they have adequate mechanical characteristics and transition zone with the cementitious matrix [25]. In turn, the w/c ratio had significant influence on the compressive strength of concrete as expected. The reduction of the w/c ratio results in a more compact cementitious matrix, reducing its porosity and consequently increasing the mechanical resistance of the materia $[24,26]$.

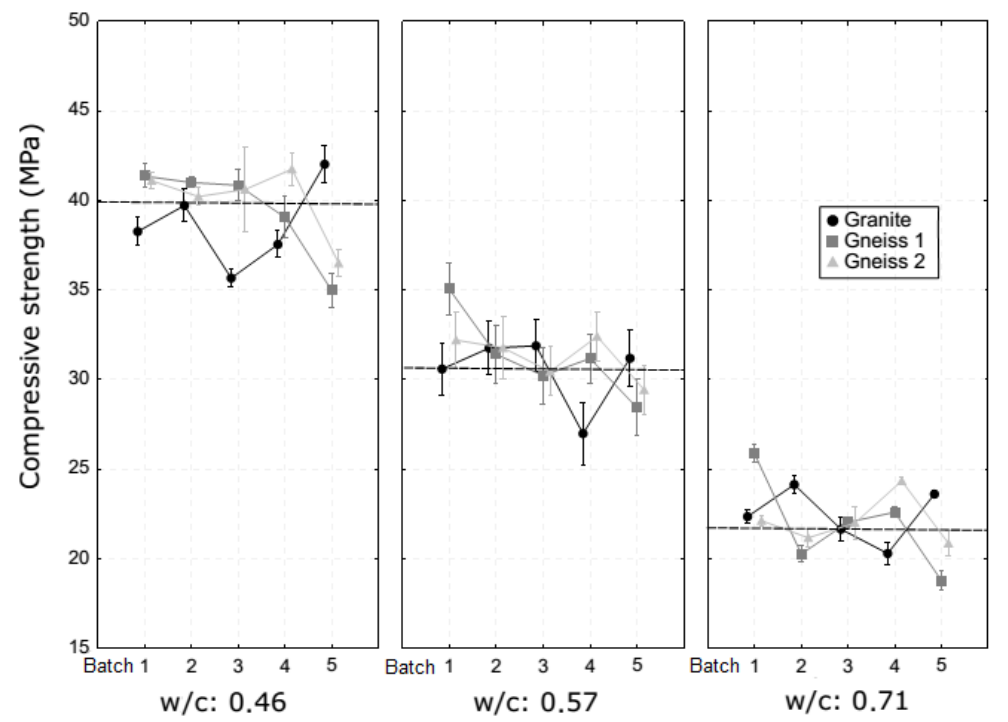

Figure 4: Compressive strength of the concretes at 28 days for the different w/c ratios, type and batch of aggregate. 
Table 3: ANOVA: influence of "w/c ratio", "aggregate type" and "aggregate batch" on the compressive strength of concrete.

\begin{tabular}{lllllll}
\hline Source & SS & DOF & MS & F & p & Significant? \\
\hline w/c ratio (A) & 14884.2 & 2 & 7442.08 & 1908.25 & 0 & Yes \\
Aggregate type (B) & 19.262 & 2 & 9.631 & 2.47 & 0.087 & No \\
Aggregate batch (C) & 217.733 & 4 & 54.433 & 13.957 & 0 & Yes \\
AB & 31.088 & 4 & 7.772 & 1.993 & 0.096 & No \\
AC & 36.995 & 8 & 4.624 & 1.186 & 0.308 & No \\
BC & 585.486 & 8 & 73.186 & 18.766 & 0 & Yes \\
ABC & 197.94 & 16 & 12.371 & 3.172 & 0 & Yes \\
Error & 1013.99 & 260 & 3.9 & & & \\
Total & 16986.7 & 304 & & & & \\
\hline
\end{tabular}

SS: sum of squares; DOF: degrees of freedom; MS: mean square; F: F-statistic; p: probability value.

\subsection{Modulus of elasticity of concrete}

Figure 5 shows the average values of the modulus of elasticity of the concretes for each ratio w/c, type and batch of aggregate. ANOVA presented in

Table 4 indicated that the three factors had significant influence on the module of elasticity, as well as the interactions between them, for $95 \%$ reliability. The influence of each factor will be discussed independetly in the following items. However, it is evident in Figure 5 that the values obtained for the granitic aggregate are lower than those obtained for the gneissic aggregates for the same w/c ratio, while the values obtained for the two gneissic aggregates did not have significant differences.

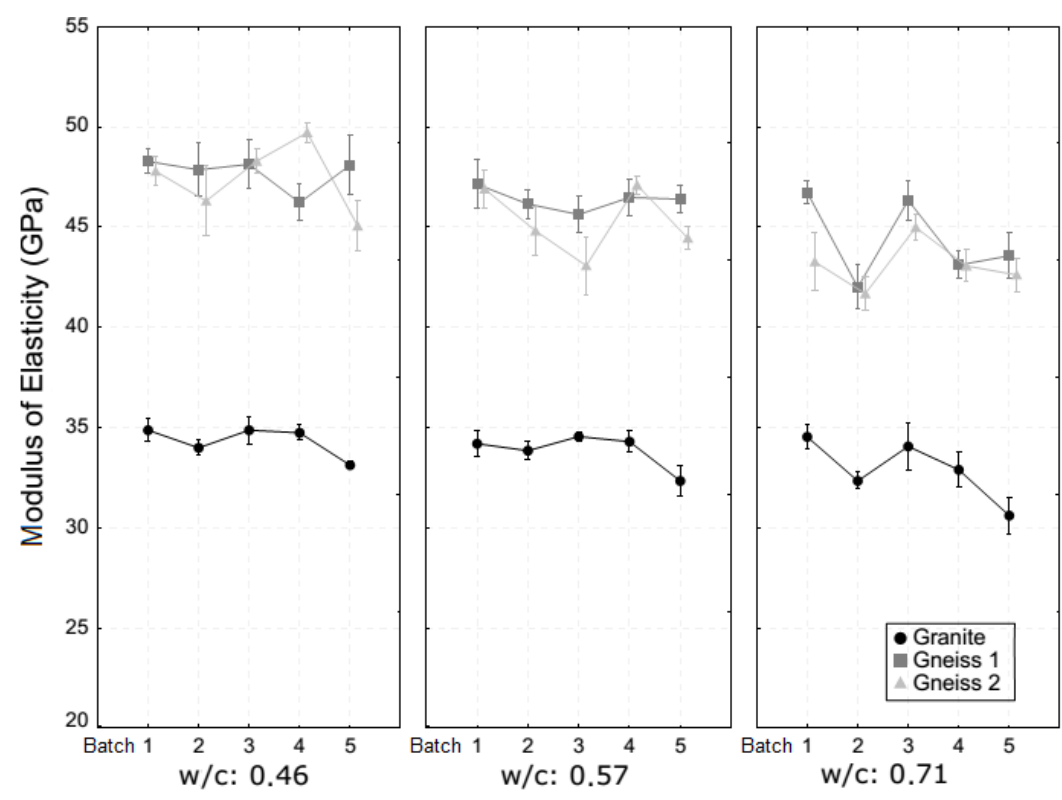

Figure 5: Modulus of elasticity of the concretes at 28 days for the different w/c ratios, type and batch of aggregate. 
Table 4: ANOVA: influence of "w/c ratio", "aggregate type" and "aggregate batch" on the modulus of elasticity of concrete.

\begin{tabular}{lllllll}
\hline Source & SS & DOF & MS & F & p & Significant? \\
\hline w/c ratio (A) & 311.891 & 2 & 155.945 & 39.959 & 0 & Yes \\
Aggregate type (B) & 6309.73 & 2 & 3154.865 & 808.386 & 0 & Yes \\
Aggregate batch (C) & 109.964 & 4 & 27.491 & 7.044 & 0 & Yes \\
AB & 49.06 & 4 & 12.265 & 3.143 & 0.016 & Yes \\
AC & 65.488 & 8 & 8.186 & 2.098 & 0.039 & Yes \\
BC & 66.65 & 8 & 8.331 & 2.135 & 0.035 & Yes \\
ABC & 67.578 & 16 & 4.224 & 1.082 & 0.376 & No \\
Error & 643.94 & 165 & 3.903 & & & \\
Total & 7624.302 & 209 & & & & \\
\hline
\end{tabular}

\subsubsection{Effect of "type of aggregate" on the modulus of elasticity of concrete}

ANOVA presented in

Table 4 indicated that the factor "aggregate type" had a more significant influence on the modulus of elasticity of concrete than the factor "w/c ratio" since the F index of the former was higher than that of the latter. This behavior was opposite to that observed in the compressive strength, where the type of aggregate did not have significant influence, while the "w/c ratio" played a major role. According to [24], properties such as the modulus of elasticity and density of the constituent phases, their volumetric fraction and the properties of the transition zone are preponderant in the elastic behavior of concrete. Thus, the use of aggregate with higher modulus of elasticity naturally increases the overall modulus of elasciticy of concrete. In this context, it was observed that concretes produced with granitic aggregates presented values of modulus of elasticity approximately 30\% lower than those obtained for concretes containing gneissic aggregates, regardless of the strength level (i.e. w/c ratio) and aggregate batch. Similar behaviors to those observed in this work are reported by other authors in the literature [27-31].

Furthermore, Duncan post-hoc test was conducted to check if the type of gneiss led to significant differences in the values of modulus of elasticity, and the results are presented in Table 5. For the same w/c ratios, no significant differences between the modules of elasticity of the concretes produced with the different gneissic aggregates were observed, with 95\% reliability. This reinforces the hypothesis that the mineralogical type of aggregate is the predominant parameter in the elastic behavior of concrete, for a fixed content of it.

Table 5: Duncan test for the modulus of elasticity of the concretes with different gneissic aggregates.

\begin{tabular}{|c|c|c|c|c|c|c|c|c|c|}
\hline \multicolumn{2}{|r|}{ Mix } & \multirow{2}{*}{$\begin{array}{c}\text { Eci } \\
\text { (GPa) }\end{array}$} & \multirow{2}{*}{$\begin{array}{c}\text { Std } \\
(\mathrm{GPa})\end{array}$} & \multirow{2}{*}{$\begin{array}{l}0.71 \\
\text { GN1 }\end{array}$} & \multirow{2}{*}{$\begin{array}{l}0.71 \\
\text { GN2 }\end{array}$} & \multirow{2}{*}{$\begin{array}{l}0.57 \\
\text { GN1 }\end{array}$} & \multirow{2}{*}{$\begin{array}{l}0.57 \\
\text { GN2 }\end{array}$} & \multirow{2}{*}{$\begin{array}{l}0.46 \\
\text { GN1 }\end{array}$} & \multirow{2}{*}{$\begin{array}{l}0.46 \\
\text { GN2 }\end{array}$} \\
\hline$w / c$ & Aggregate & & & & & & & & \\
\hline 0.71 & GN1 & 44.3 & 2.52 & - & NS & $S$ & NS & S & S \\
\hline 0.71 & GN2 & 43.0 & 2.36 & NS & - & $S$ & $S$ & $S$ & $S$ \\
\hline 0.57 & GN1 & 46.4 & 1.93 & S & $S$ & - & NS & NS & NS \\
\hline 0.57 & GN2 & 45.4 & 2.29 & NS & $S$ & NS & - & $S$ & $S$ \\
\hline 0.46 & GN1 & 47.6 & 1.87 & $\mathrm{~S}$ & $S$ & NS & $\mathrm{S}$ & - & NS \\
\hline
\end{tabular}




\begin{tabular}{lllllllllll}
0.46 & GN2 & 47.4 & 2.72 & S & S & NS & S & NS & - \\
\hline
\end{tabular}

Eci = modulus of elasticity; $\mathrm{Std}=$ standard deviation; $\mathrm{S}=$ significant difference; $\mathrm{NS}=$ not significant difference.

\subsubsection{Effect of "w/c ratio" on the modulus of elasticity of concrete}

Figure 6 shows the values of the modulus of elasticity of the concretes as a function of their compressive strength, for each type of aggregate. There was a slight upward trend in the module of elasticity with the reduction of the w/c ratio (i.e. with the increase in the strength of concrete). This trend was confirmed by ANOVA presented in

Table 4, with 95\% reliability. Although the factor "w/c ratio" statistically influenced the modulus of elasticity, this trend was discreet: in the case of concretes containing granitic aggregate, reducing the w/c ratio from 0.71 to 0.46 increased the modulus of elasticity from $33.0 \mathrm{GPa}$ to $34.0 \mathrm{GPa}$ (about $3 \%$ increase); in the case of the concretes containing gneissic aggregates, this increase was slightly higher, from $44.3 \mathrm{GPa}$ to 47.6 GPa (about 7\% increase). These increases were much lower than the $80 \%$-increase in compressive strength promoted by the reduction of the w/c ratio from 0.71 to 0.46 . These results reinforce the hypothesis that an increase in compressive strength does not necessarily lead to significant increases in its modulus of elasticity. In fact, this is verified by [4], which obtained modulus from 38 to $46 \mathrm{GPa}$ for ultra-high performance concretes with compressive strengths of 130-160 MPa, with strengths much higher than those obtained in the present work but similar modules.

As already mentioned, the reduction of the w/c ratio results in a more compact cementitious matrix, with smaller pore volumes. However, in this study, the water consumption of the mixtures was kept fixed for all compositions, with the reduction of the w/c ratio effected by the increase in the cement consumption of the concretes. This led to increases in paste volume of up to $5 \%$ when comparing concretes with a w/c ratio of 0.71 and 0.46 , since the volume of coarse aggregates and the content of mortar were kept constant for all mixtures. It is known that the modulus of elasticity of aggregates is, in general, much higher than that of cement paste [32]. Thus, the increase in the modulus of elasticity of concrete promoted by the increase in the stiffness of the paste (resulting from the reduction of the w/c ratio) was partially compensated by the increase in the volume of paste (the latter, with a lower modulus of elasticity). These results are compatible with those reported by [2]: according to the authors, the cement paste of self-compacting concrete have a module of elasticity $5-15 \%$ higher than the paste of conventional concrete, justified by the increase in compactness promoted by the addition of filler. Despite that, self-compacting concrete showed modulus of elasticity about $5 \%$ lower than conventional concrete for the same compressive strength due to the higher volumes of paste of the former.

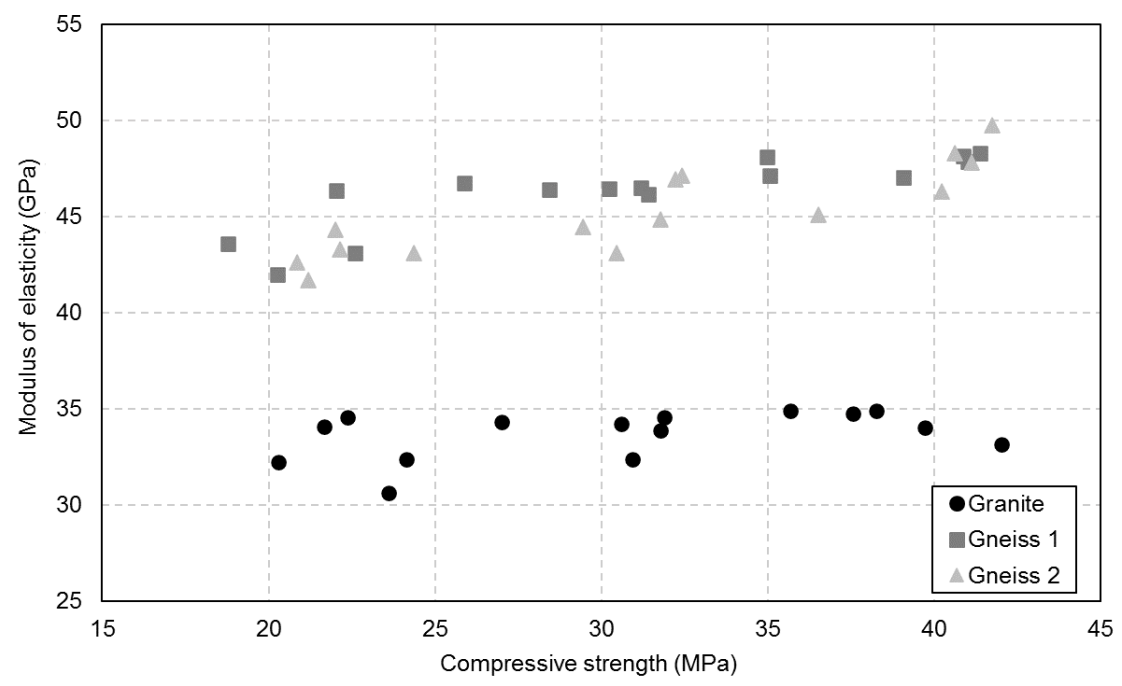

Figure 6: Modulus of elasticity of concrete as a function of its compressive strength. 


\subsubsection{Effect of "aggregate batch" on the modulus of elasticity of concrete}

In order to evaluate the variability of the modulus of elasticity of concretes produced with aggregates from the same source extracted over time, ANOVA was conducted to check the influence of the factor "aggregate batch" on its property for each aggregate source separately. The results are presented in

Table 6. The aggregate batch had significant influence on the module of elasticity of concrete, with $95 \%$ reliability, regardless of the aggregate type. This behavior suggests a probabilistic approach for this property, and not deterministic values resulting from specific tests, or simply correlated to compressive strength as often adopted in practice. Such a probabilistic approach is also suggested by other authors [33-35].

Table 6: ANOVA: effect of "aggregate batch" on the modulus of the elasticity of concrete, for each type of aggregate.

\begin{tabular}{|c|c|c|c|c|c|c|c|}
\hline Aggregate & Source & SS & DOF & MS & $\mathbf{F}$ & p & Significant? \\
\hline & w/c ratio $(\mathrm{A})$ & 23.495 & 2 & 11.747 & 5.728 & 0.006 & Yes \\
\hline & Aggregate batch (B) & 52.093 & 4 & 13.023 & 6.35 & 0 & Yes \\
\hline \multirow[t]{5}{*}{ GR } & $\mathrm{AB}$ & 9.93 & 8 & 1.241 & 0.605 & 0.769 & No \\
\hline & Error & 108.693 & 53 & 2.051 & & & \\
\hline & Total & 194.21 & 67 & & & & \\
\hline & w/c ratio $(\mathrm{A})$ & 117.883 & 2 & 58.942 & 15.211 & 0 & Yes \\
\hline & Aggregate batch (B) & 43.087 & 4 & 10.772 & 2.78 & 0.036 & Yes \\
\hline \multirow[t]{5}{*}{ GN1 } & $\mathrm{AB}$ & 45.549 & 8 & 5.694 & 1.469 & 0.191 & No \\
\hline & Error & 201.496 & 52 & 3.875 & & & \\
\hline & Total & 408.015 & 66 & & & & \\
\hline & w/c ratio $(\mathrm{A})$ & 219.17 & 2 & 109.585 & 22.864 & 0 & Yes \\
\hline & Aggregate batch (B) & 78.653 & 4 & 19.663 & 4.103 & 0.005 & Yes \\
\hline \multirow[t]{3}{*}{ GN2 } & $\mathrm{AB}$ & 69.774 & 8 & 8.722 & 1.82 & 0.092 & No \\
\hline & Error & 277.991 & 58 & 4.793 & & & \\
\hline & Total & 426.419 & 70 & & & & \\
\hline
\end{tabular}

\subsection{Normality and estimation of characteristic value of modulus of elasticity}

Since the modulus of elasticity behaves as a probabilistic variable, it can assume different frequency patterns depending on the sample data. When it comes to experimental data, it is known that several phenomena are well described by the normal distribution [36]. Thus, to assume this premise in this work, it was verified whether the data set adheres to normality, by the Kolmogorov-Smirnov Normalty Test described in item 2.6. The results are shown in Table 7 . It was found with $95 \%$ reliability that the values of modulus of elasticity obtained follow normality, for all types of coarse aggregate and w/c ratio. 
Table 7: Kolmogorov-Smirnov Normality Test for the modulus of elasticity of concrete.

\begin{tabular}{|c|c|c|c|c|c|c|c|}
\hline Mix & & Eci (GPa) & Std (GPa) & $n$ & Dmax & $\mathrm{Da}(\mathrm{n})$ & Normality \\
\hline 0.46 & GR & 34.4 & 1.25 & 21 & 0.1815 & 0.188 & Normal \\
\hline 0.57 & & 33.9 & 1.28 & 22 & 0.1211 & 0.186 & Normal \\
\hline 0.71 & & 33.0 & 2.12 & 25 & 0.1207 & 0.180 & Normal \\
\hline 0.46 & GN1 & 47.6 & 1.87 & 21 & 0.1176 & 0.188 & Normal \\
\hline 0.57 & & 46.4 & 1.93 & 23 & 0.1776 & 0.184 & Normal \\
\hline 0.71 & & 44.3 & 2.52 & 23 & 0.1041 & 0.184 & Normal \\
\hline 0.46 & GN2 & 47.4 & 2.72 & 25 & 0.1430 & 0.180 & Normal \\
\hline 0.57 & & 45.4 & 2.29 & 23 & 0.1060 & 0.184 & Normal \\
\hline 0.71 & & 43.0 & 2.36 & 25 & 0.1077 & 0.180 & Normal \\
\hline
\end{tabular}

The normality of the data indicates that there is a probability of obtaining higher and lower values than the value experimentally determined. Thus, to ensure the safety of structural projects, it is proposed to adopt characteristic values for the concrete elasticity module (Eck). For this, the t-student distribution described in item 2.6 was used. The results of this analysis are shown in

Table 8. The Eck values are, in general, 2.0 to $4.5 \mathrm{GPa}$ lower than the average values experimentally obtained (i.e. from 6 to $11 \%$ lower). This indicates that the adoption of average values for the structural calculation can result in considerable errors, leading to excessive deformations of the structures.

Table 8: Determination of the characteristic value of the modulus of elasticity (Eck) of concrete.

\begin{tabular}{llllllll}
\hline Mix & & Eci (GPa) & Std & $\mathbf{n}$ & $\mathbf{t}$ & Probability (\%) & Eck (GPa) \\
\hline 0.46 & GR & 34.4 & 1.25 & 21 & -13.763 & 100 & 32.3 \\
0.57 & & 33.9 & 1.28 & 22 & -21.586 & 100 & 31.7 \\
0.71 & & 33.0 & 2.12 & 25 & -26.717 & 100 & 29.4 \\
\hline 0.46 & GN1 & 47.6 & 1.87 & 21 & -41.549 & 100 & 44.4 \\
0.57 & & 46.4 & 1.93 & 23 & -45.622 & 100 & 43.1 \\
0.71 & & 44.3 & 2.52 & 23 & -43.033 & 100 & 40.0 \\
\hline 0.46 & GN2 & 47.4 & 2.72 & 25 & -30.836 & 100 & 42.8 \\
0.57 & & 45.4 & 2.29 & 23 & -36.456 & 100 & 41.5 \\
0.71 & & 43.0 & 2.36 & 25 & -45.218 & 100 & 39.0 \\
\hline
\end{tabular}

\section{CONCLUSIONS}

In this work, the influence of the coarse aggregate batch on the variability of the modulus of elasticity of concrete was evaluated. Based on the results obtained, some conclusions can be drawn.

- ANOVA indicated that the aggregate batch had significant influence on the modulus of elasticity of concrete for a $95 \%$ reliability. This suggests that such property should be treated as a probabilistic variable, and not a deterministic one as it is currently addressed.

- The normal distribution for the modulus of elasticity was confirmed by the Kolmogorov-Smirnov Normality Test. A characteristic modulus of elasticity (Eck) was proposed, below which no experimental values will be obtained for $95 \%$ reliability. The proposed Eck values were 6 to $11 \%$ lower than the average values, indicating that the adoption of the average values for structural calculations may result in considerable errors and lead to excessive deformations.

- The type of aggregate had no significant influence on the compressive strength of concrete, despite being the factor that most influenced the modulus of elasticity. Concretes containing granitic aggregate showed modulus of elasticity about 30\% lower than those containing gneissic aggregates for the same compressive strengths. The w/c ratio significantly influenced the modulus of elasticity of the concretes, albeit 
in a discrete way: a reduction in the w/c ratio from 0.71 to 0.46 increased the modulus by $3 \%-7 \%$, while increasing compressive strength by about $80 \%$. Thus, it was evident that increasing the compressive strength of concrete is not an effective alternative to increase its modulus of elasticity.

\section{ACKNOWLEDGEMENTS}

The authors would like to thank CAPES (Coordination for the Improvement of Higher Education Personnel), CNPq (processes $n^{\circ}$ 99999.008308/2014-04 and 99999.008307/2014-08) and FAPESC (Foundation for the Support of Research in the State of Santa Catarina) for financial support, and to LabNANOTEC-UFSC (Laboratory of Nanotechnology Applications in Civil Construction) for the infrastructure.

\section{CONFLICT OF INTEREST}

None declared.

\section{BIBLIOGRAPHY}

[1] DE MATOS, P.R., JUNCKES, R., PRUDÊNCIO JR, L.R. "Influência do uso de cinza volante na elevação adiabática de temperatura e resistência à compressão de concretos", Matéria (Rio de Janeiro), v. 24, n. 2, pp e-12359, 2019.

[2] PARRA, C., VALCUENDE, M., GÓMEZ, F. "Splitting tensile strength and modulus of elasticity of selfcompacting concrete", Construction and Building Materials, v. 25, n. 1, pp. 201-207, 2011.

[3] ABED, A.M., NEMES, R., NEHME, S. "Residual Modulus of Elasticity of Self-Compacting Concrete Incorporated Unprocessed Waste Fly Ash after Expose to the Elevated Temperature", International Journal of Civil and Environmental Engineering, v. 13, n. 9, 2019.

[4] ALSALMAN, A., DANG, C.N., MICAH HALE, W. "Development of ultra-high performance concrete with locally available materials", Construction and Building Materials, v. 133, pp. 135-145, 2017.

[5] SILVA, R.V., DE BRITO, J., DHIR, R.K. "Establishing a relationship between modulus of elasticity and compressive strength of recycled aggregate concrete", Journal of Cleaner Production, v. 112, pp. 2171-2186, 2016.

[6] JUROWSKI, K., GRZESZCZYK, S. "The influence of concrete composition on Young's modulus". Procedia Engineering. v. 108, pp. 584-591, 2015.

[7] SCHANKOSKI, R.A., PILAR, R., DE MATOS, P.R., et al. "Fresh and hardened properties of selfcompacting concretes produced with diabase and gneiss quarry by-product powders as alternative fillers", Construction and Building Materials, v. 224, pp. 659-670, 2019.

[8] FIB, Model Code 2010, 2012.

[9] ACI. 318-19, Building Code Requirements for Structural Concrete and Commentary, 2019.

[10] ABNT, NBR 6118: Projeto de estruturas de concreto - Procedimento. 2014. ISBN 9788507026815

[11] EN, Eurocode 2: Design of concrete structures, 1992.

[12] EHE-08. Instrucción de Hormigon Estructural. B.m: Centro de Publicaciones Secretaria General Tecnica Ministerio de Fomento, 2008.

[13] NZS 3106, Design of Concrete Structures for the Storage of Liquids, 2009.

[14] CSA, CSA A23.3: Design of concrete structures, 2004.

[15] ABNT NBR 16697: Cimento Portland-Requisitos, 2018.

[16] EN 197-1, Composition, specifications and conformity criteria for common cements. Brussels: CEN, 2011.

[17] MATOS, R.P., SAKATA, D.R., PRUDÊNCIO, R. "Eco-efficient low binder high-performance selfcompacting concretes", Construction and Building Materials, v. 225, pp. 941-955, 2019.

[18] DE MATOS, P.R., PRUDÊNCIO JR., L.R., PILAR, R., et al.. "Use of recycled water from mixer truck wash in concrete: Effect on the hydration, fresh and hardened properties", Construction and Building Materials, v. 230, p. 116981, 2020.

[19] ASTM C143: Standard Test Method for Slump of Hydraulic-Cement Concrete, pp. 1-4, 2015. 
[20] ASTM C185: Standard Test Method for Air Content of Hydraulic Cement Mortar, West Conshohocken, PA, 2015.

[21] ASTM C39: Standard Test Method for Compressive Strength of Cylindrical Concrete Specimens, pp. 17, 2015.

[22] ASTM C469: Standard Test Method for Static Modulus of Elasticity and Poisson's Ratio of Concrete in Compression, 2014.

[23] CORDER, G.W., FOREMAN, D.I. "Nonparametric Statistics for Non-Statisticians: A Step-by-Step Approach", New Jersey: John Wiley \& Sons, 2013.

[24] MEHTA, P.K., MONTEIRO, P.J.M. "Concrete: Microstructure, properties and materials”, In: 3rd editio. B.m.: The McGraw-Hill Companies, 2014.

[25] MALHOTRA, V.M., HELENE, P., PRUDENCIO JR, L.R., et al. ACI SP-186 : High-Performance Concrete : Performance and Quality of Concrete Structures, 2002.

[26] NEVILLE, A.M. "Properties of Concrete”, In: 5th ed. B.m: Pearson, 2011.

[27] AHMAD, S. ALGHAMDI, S.A. "A Study on Effect of Coarse Aggregate Type on Concrete Performance", Arabian Journal for Science and Engineering, v. 37, n. 7, pp. 1777-1786, 2012.

[28] BEUSHAUSEN, H., DITTMER, T. "The influence of aggregate type on the strength and elastic modulus of high strength concrete", Construction and Building Materials, v. 74, pp. 132-139, 2015.

[29] RASHID, M.A., MANSUR, M.A., PARAMASIVAM, P. "Correlations between mechanical properties of high-strength concrete", Journal of Materials in Civil Engineering, v. 14, n. 3, pp. 230-238, 2002.

[30] UYSAL, M. "The influence of coarse aggregate type on mechanical properties of fly ash additive selfcompacting concrete", Construction and Building Materials, v. 37, pp. 533-540, 2012.

[31] ESTOLANO, V., FUCALE, S., VIEIRA FILHO, J.O., et al. "Avaliação dos módulos de elasticidade estático e dinâmico de concretos produzidos com agregados reciclados oriundos de resíduos de préfabricados de concreto", Matéria (Rio Janeiro), v. 23, n. 1, 2018.

[32] PIASTA, W., GÓRA, J., BUDZYŃSKI, W. "Stress-strain relationships and modulus of elasticity of rocks and of ordinary and high performance concretes", Construction and Building Materials, v. 153, pp. 728-739, 2017.

[33] MARCHI, R. Estudo sobre a variabilidade do módulo de deformação do concreto associada a fatores intrínsecos à produção do material, Universidade de São Paulo, 2011.

[34] MONTIJA, F.C. Aspectos da variabilidade experimental do ensaio de módulo de deformação do concreto, Universidade de São Paulo, 2007.

[35] BORIN, L.A., BAUER, R.J.F., FIGUEIREDO, A.D. "Risco de rejeição de concretos devido à não conformidade com os parâmetros normalizados para o módulo de elasticidade", Construindo, vol. 4, no. 2, pp. 79-89, 2012.

[36] MONTGOMERY, D.C., RUNGER, G.C. "Estatística aplicada e probabilidade para engenheiros”, 2003.

\section{ORCID}

Alex Taira de Vasconcellos Paulo Ricardo de Matos Cézar Augusto Casagrande André Valmir Saugo Ribeiro Luiz Roberto Prudêncio Jr. https://orcid.org/0000-0002-1386-1112 https://orcid.org/0000-0002-3695-1356 https://orcid.org/0000-0002-4293-6574 https://orcid.org/0000-0003-1156-0938 https://orcid.org/0000-0002-7594-7077 